\title{
The Mud Creek Site in the Angelina River Basin, Cherokee County, Texas
}

Timothy K. Perttula

Heritage Research Center, Stephen F. Austin State University

Bo Nelson

Heritage Research Center, Stephen F. Austin State University

Follow this and additional works at: https://scholarworks.sfasu.edu/ita

Part of the American Material Culture Commons, Archaeological Anthropology Commons, Environmental Studies Commons, Other American Studies Commons, Other Arts and Humanities Commons, Other History of Art, Architecture, and Archaeology Commons, and the United States History Commons

Tell us how this article helped you.

This Article is brought to you for free and open access by the Center for Regional Heritage Research at SFA ScholarWorks. It has been accepted for inclusion in Index of Texas Archaeology: Open Access Gray Literature from the Lone Star State by an authorized editor of SFA ScholarWorks. For more information, please contact cdsscholarworks@sfasu.edu. 


\section{The Mud Creek Site in the Angelina River Basin, Cherokee County, Texas \\ Creative Commons License \\ (c) (1) \& 8}

This work is licensed under a Creative Commons Attribution-NonCommercial 4.0 International License 


\title{
The Mud Creek Site in the Angelina River Basin, Cherokee County, Texas
}

\author{
Timothy K. Perttula and Bo Nelson
}

\section{INTRODUCTION}

There are four vessels in the Buddy Jones collection at the Gregg County Historical Museum from the Mud Creek site, also known as the Damon Ramey site; it has not been formally recorded and does not have a state trinomial. This site is near Reklaw, Texas, by U.S. 84 where it crosses Mud Creek, a major southwardflowing tributary to the Angelina River (Figure 1). Bill Young, now deceased, had told the senior author several years ago about a Caddo cemetery at this approximate location on Mud Creek.

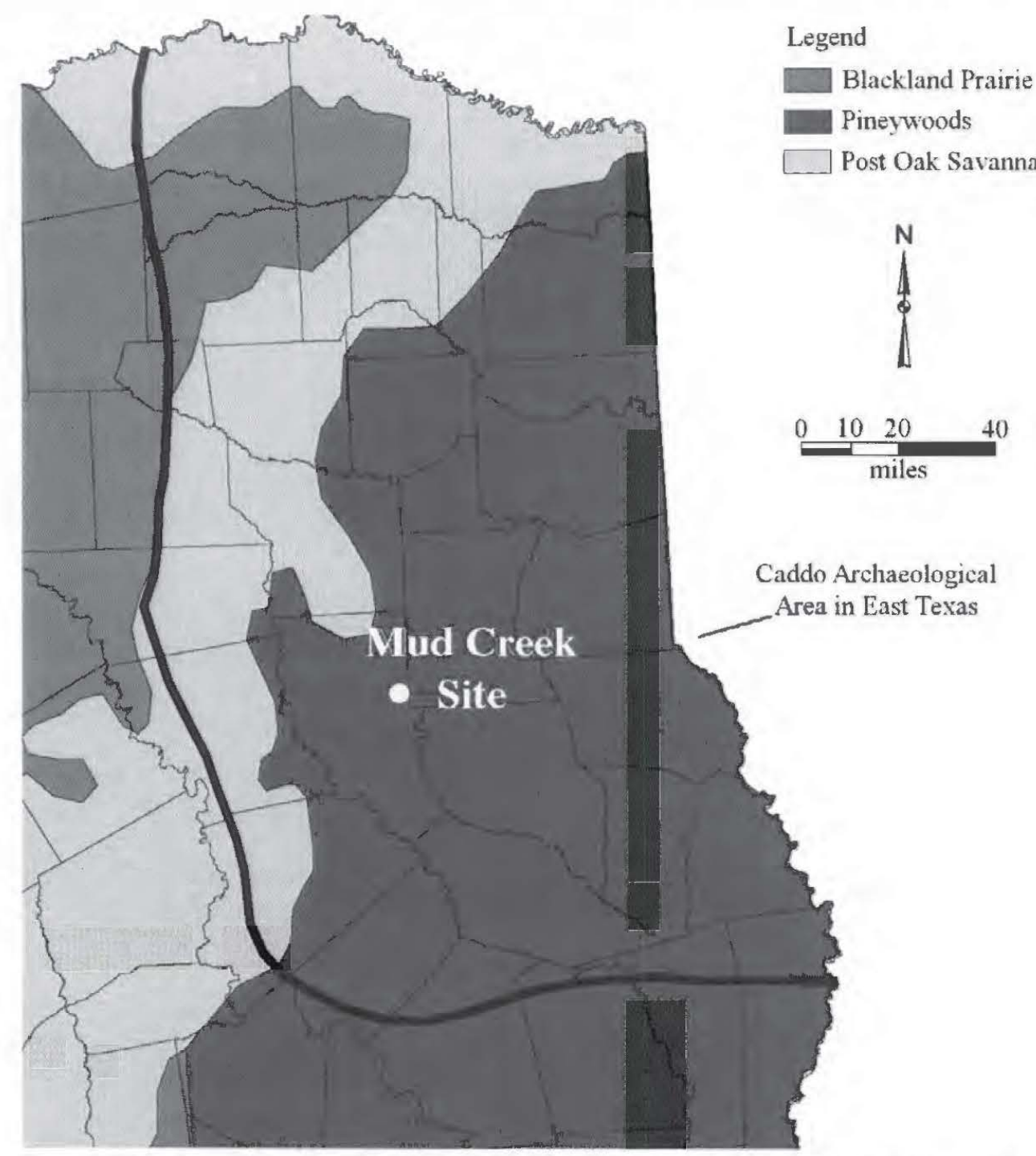

Figure 1. The location of the Mud Creek site in Cherokee County, in the East Texas Pineywoods. 
According to Jones, a total of five burials were excavated here, although it is not known if all five burials were excavated by Jones or instead by other unknown individuals. The four vessels documented from the site are from Burials 3 and 4.

\section{VESSEL RECORDATION FORMS}

\section{SITE NAME OR SITE NUMBER: Mud Creek}

VESSEL NO: \#7, 2003.08.739, Burial 3

NON-PLASTICS AND PASTE: grog/sandy paste

VESSEL FORM: Bowl

RIM AND LIP FORM: Direct rim and an exterior folded Redwine mode lip with 15 scalloped/folded edges (Figure 2c)

CORE COLOR: F (fired in a reducing environment and cooled in the open air)

INTERIOR SURFACE COLOR: reddish-brown

EXITERIOR SURFACE COLOR: reddish-brown

WALL THICKNESS (RIM, BODY, AND BASE IN MM): rim, $6.2 \mathrm{~mm}$

INTERIOR SURFACE TREATMENT: burnished

EXTERIOR SURFACE TREATMENT: burnished

HEIGHT (IN CM): 5.5

ORIFICE DIAMETER (IN CM): 17.1

DIAMETER AT BOT'TOM OF RIM OR NECK (IN CM): N/A

BASF DIAMETER (IN CM) AND SHAPE OF BASE: 7.2; flat and circular base

ESTIMATED VOLUME (IN LITERS): 0.4

DECORATION (INCILUDING MOTIF AND ELEMENTS WHEN APPARENT): The bowl is decorated with four engraved panels divided by sets of two diagonal engraved lines that extend from near the rim (and a single horizontal engraved line that encircles the vessel) to the vessel base. The panels are filled with narrow triangular-shaped hatched zones, open triangles, sets of concentric semi-circles, and hooked arm elements. No two panels have the same combination or spatial arrangement of decorative elements (Figure 2a-b).

PIGMENT USE AND 1.OCATION ON VESSEL: none

TYPE AND VARIETY [IF KNOWN]: Unidentified fine ware 

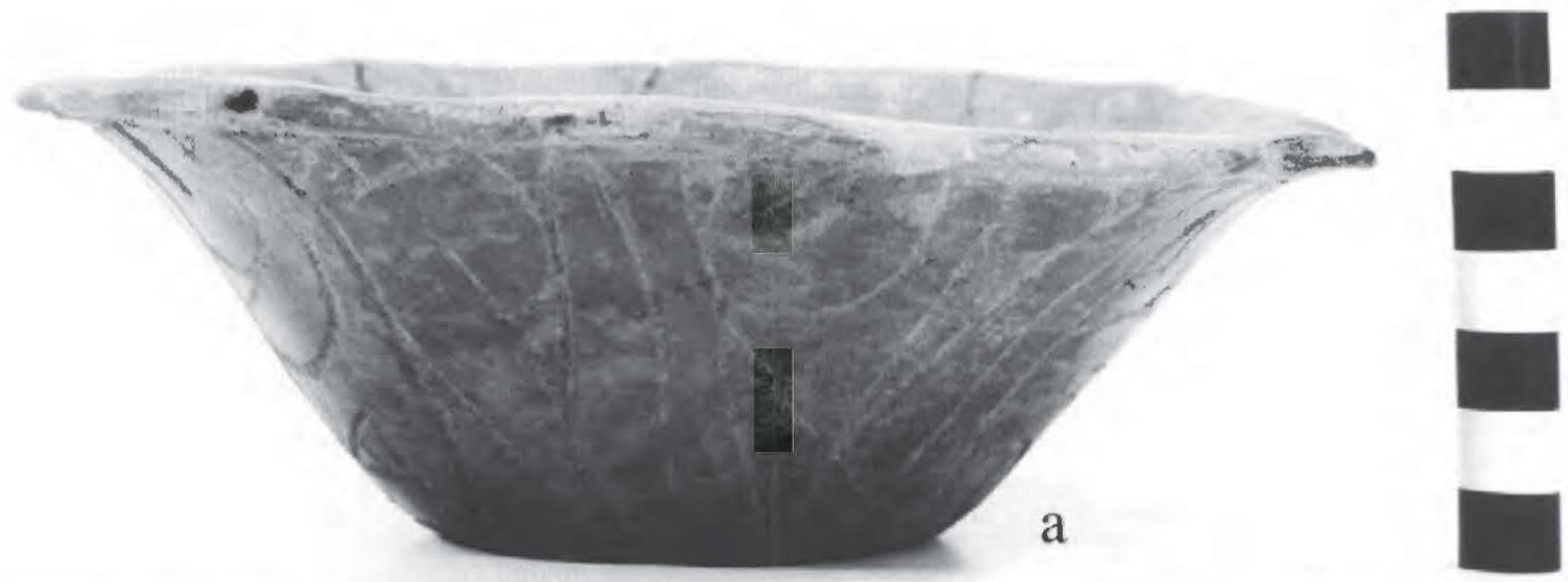

Figure 2. Engraved bowl with Redwine mode rim from Burial 3 at the Mud Creek site: a, side view; b, bottom view; c, top view showing Redwine mode rim.

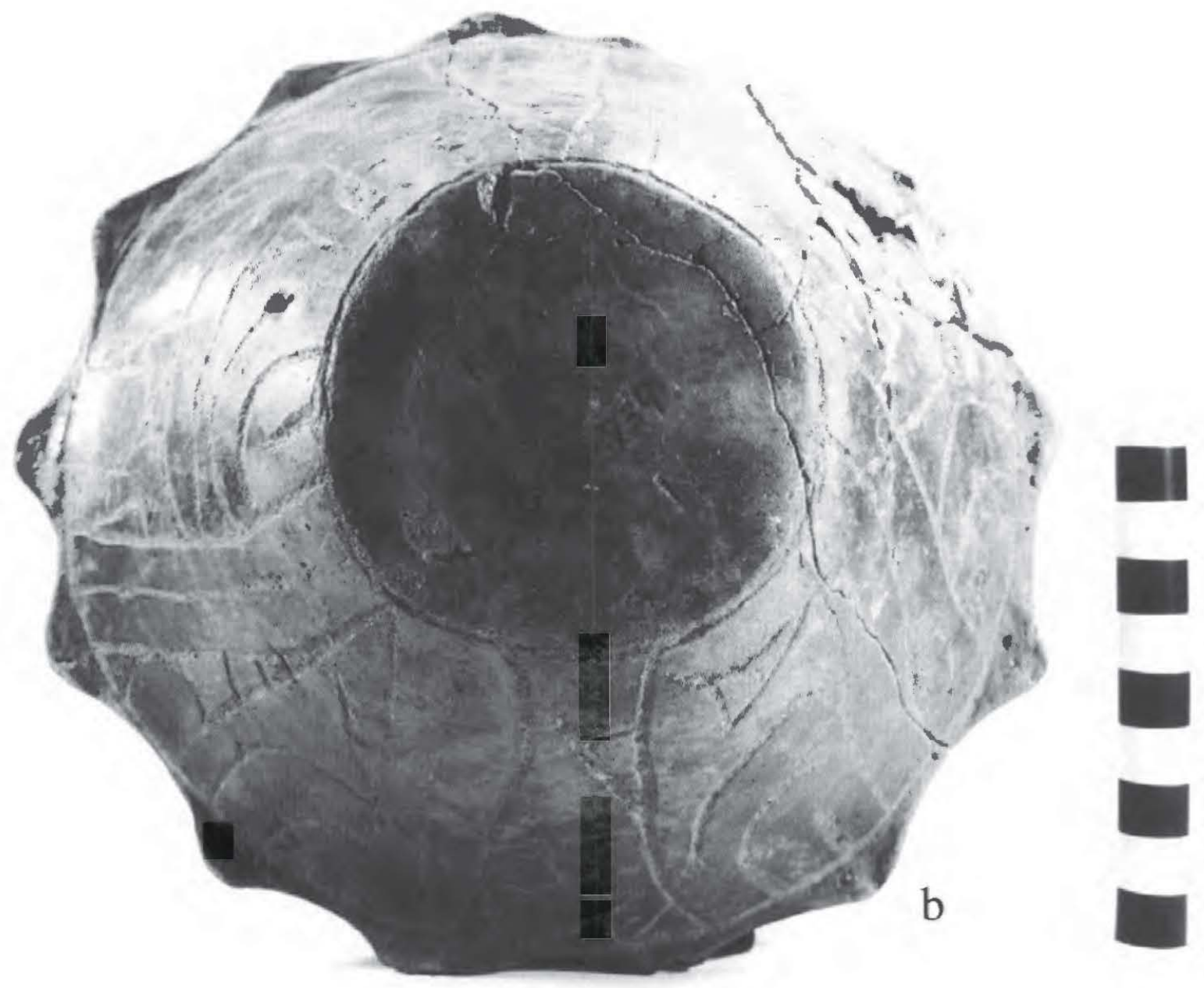



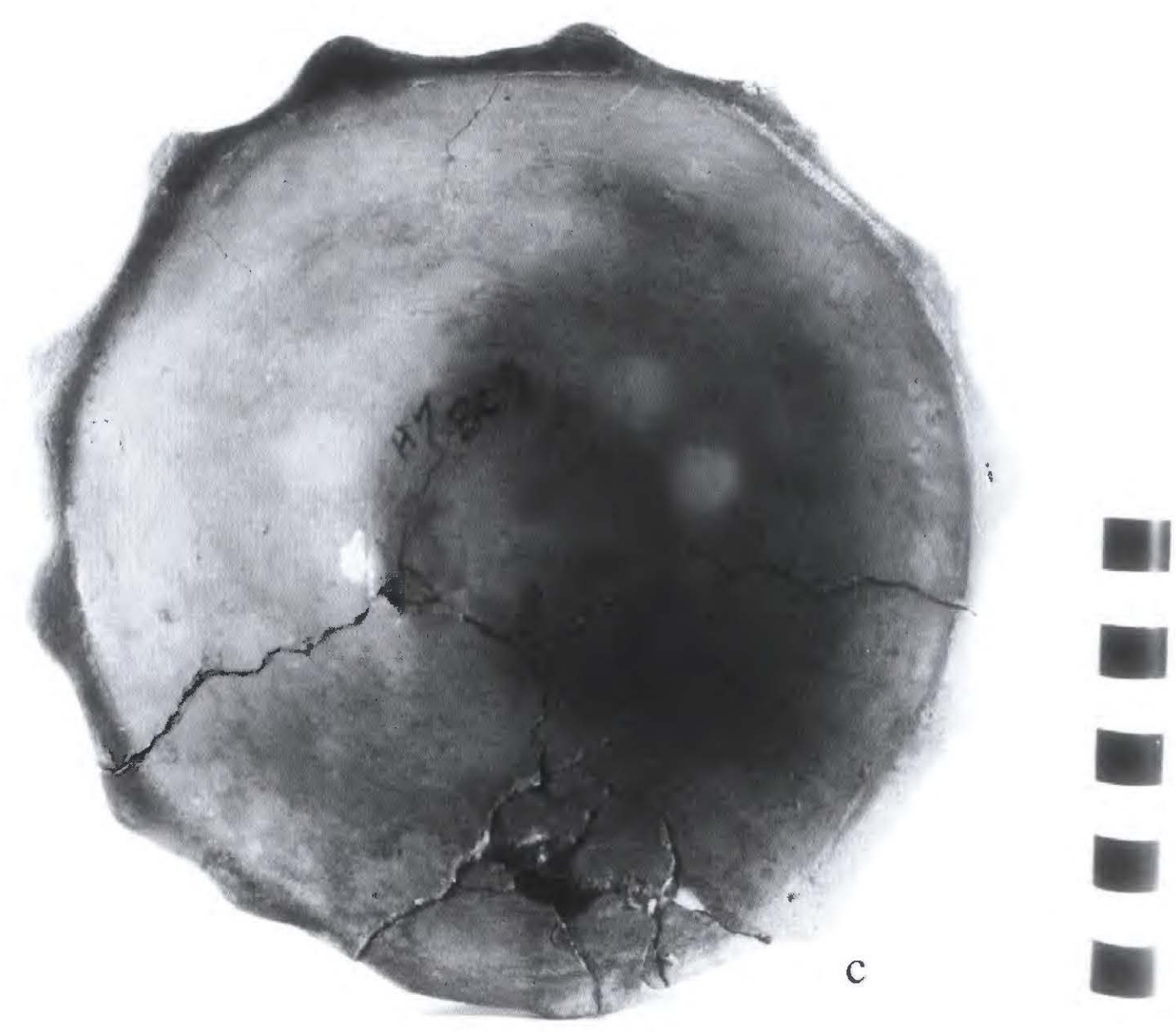

SITE NAME OR SITE NUMBER: Mud Creek

VESSEL NO:: 2003.08.789, Burial 3

NON-PLASTICS AND PASTE: grog

VESSEL FORM: Carinated bowl, globular

RIM AND LIP FORM: Direct rim and a rounded lip

CORE COLOR: F (fired in a reducing environment and cooled in the open air)

INTERIOR SURFACE COLOR: dark yellowish-brown; fire clouds on the rim and base

EXTERIOR SURFACE COLOR: dark yellowish-brown; fire clouds on the rim, body, and base

WALL THICKNESS (RIM, BODY, AND BASE IN MM): rim, 4.3 mm

INTERIOR SURFACE TREATMENT: burnished on the rim, otherwise smoothed 
EXTERIOR SURFACE TREATMENT: burnished

HEIGHT (IN CM): 11.9

ORIFICE DIAMETER (IN CM): 13.8

DIAMETER AT BOTTOM OF RIM OR NECK (IN CM): 13.4

BASE DIAMETER (IN CM) AND SHAPE OF BASE: 8.2 ; circular and flat base

ESTIMATED VOLUME (IN LITERS): 0.98

DECORATION (INCLUDING MOTIF AND ELEMENTS WHEN APPARENT): The rim is divided into seven horizontal panels by sets of narrow vertical columns. These columns are filled with sets of chevronshaped engraved lines (Figure 3).

PIGMENT USE AND LOCATION ON VESSEL: none

TYPE AND VARIETY [IF KNOWN]: cf. Poynor Engraved, var. Blackburn (Perttula 2011:Figure 6-64a-b')
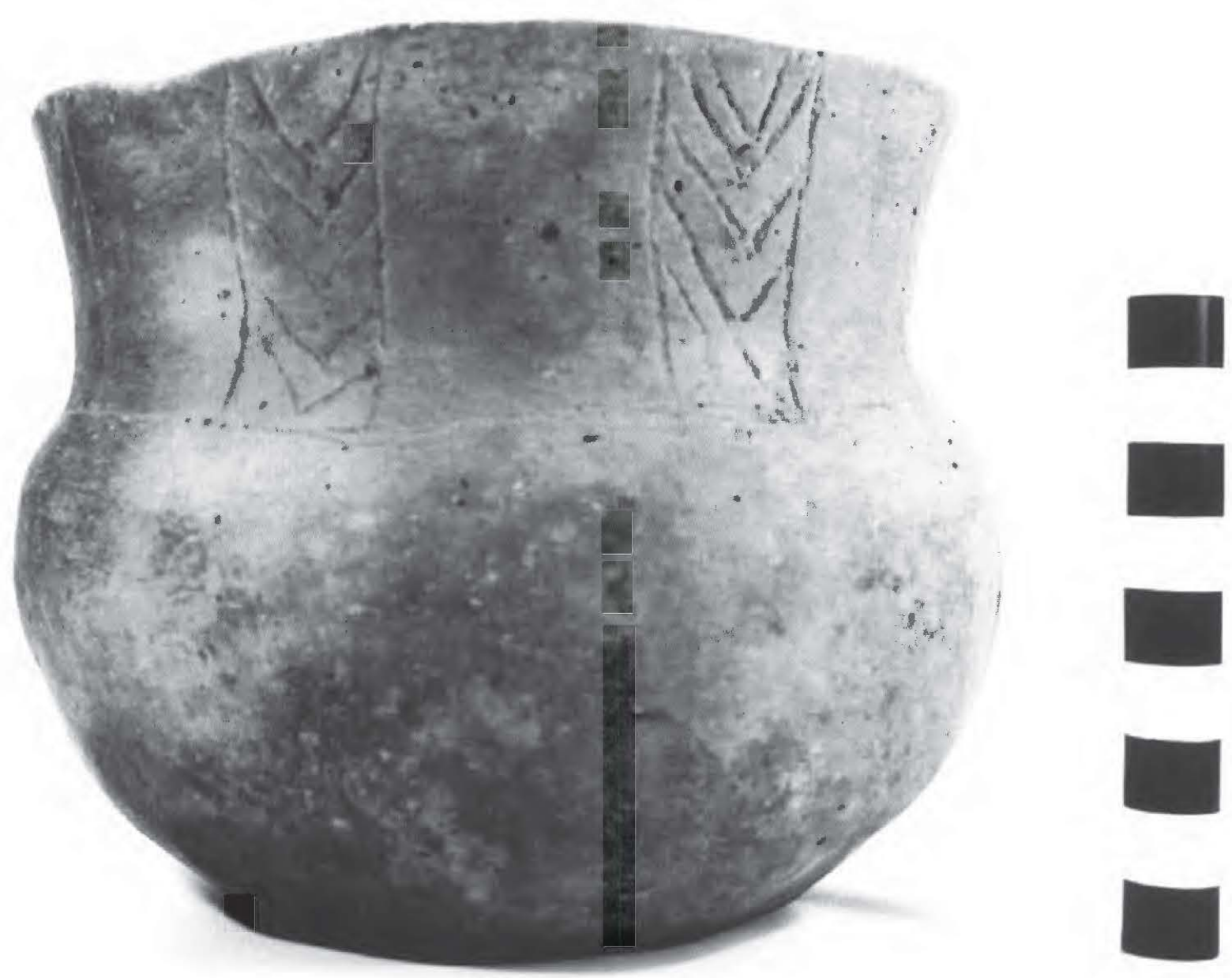

Figure 3. cf. Poynor Engraved, var. Blackburn globular carinated bowl, Burial 3 at the Mud Creek site. 


\section{SITE NAME OR SITE NUMBER: Mud Creek}

VESSEL NO.: 2003.08.1759, Burial 4

NON-I'LASTICS AND PASTE: grog/sandy paste

VESSEL FORM: Bottle

RIM AND LIP FORM: Direct rim and a flat lip

CORE COLOR: A (fired and conled in an oxidizing environment)

INTERIOR SURFACE COLOR: red

EXTERIOR SURFACE COLOR: red

WALL 'THICKNESS (RIM, BODY, AND BASE IN MM): rim, 3.9 mm

INTERIOR SURFACE TREATMENT: none

EXIERIOR SURFACE TREATMENT: burnished; possibly slipped

HEIGHT (IN CM): 15.6

ORIFICE DIAMETER (IN CM): 4.4

DIAMETER AT BOTTOM OF RIM OR NECK (IN CM): 6.7 : maximum body width of $10.3 \mathrm{~cm}$

BASE DIAMETER (IN CM) AND SHAPE OF BASE: 8.3; circular and tlat

FSTIMATED VOLUME (IN LITERS): 0.5

DECORATION (INCLUDING MOTIF AND ELEMENTS WHEN APPARENT): There is an engraved decoration on the bottle neck, and the body is plain. There are two rectangular panels with nested circles, ovals, and an interior hooked arm element (Figure 4).

PIGMENT USE AND LOCATION ON VESSEL: none

TYPE AND VARIETY [IF KNOWN]: cf. Poynor Engraved, regional var. L. (Perttula 2011:Figure 6-65).

\section{SITE NAME OR SITE NUMBER: Mud Creek}

VESSEL NO.: 2003.08.19, Burial 4

NON-PLASTICS AND PASTE: grog

VESSEL FORM: Globular four-sided carinated bowl

RIM AND LIP FORM: Everted rim and a rounded lip

CORE COLOR: B (fired and cooled in a reducing environment) 

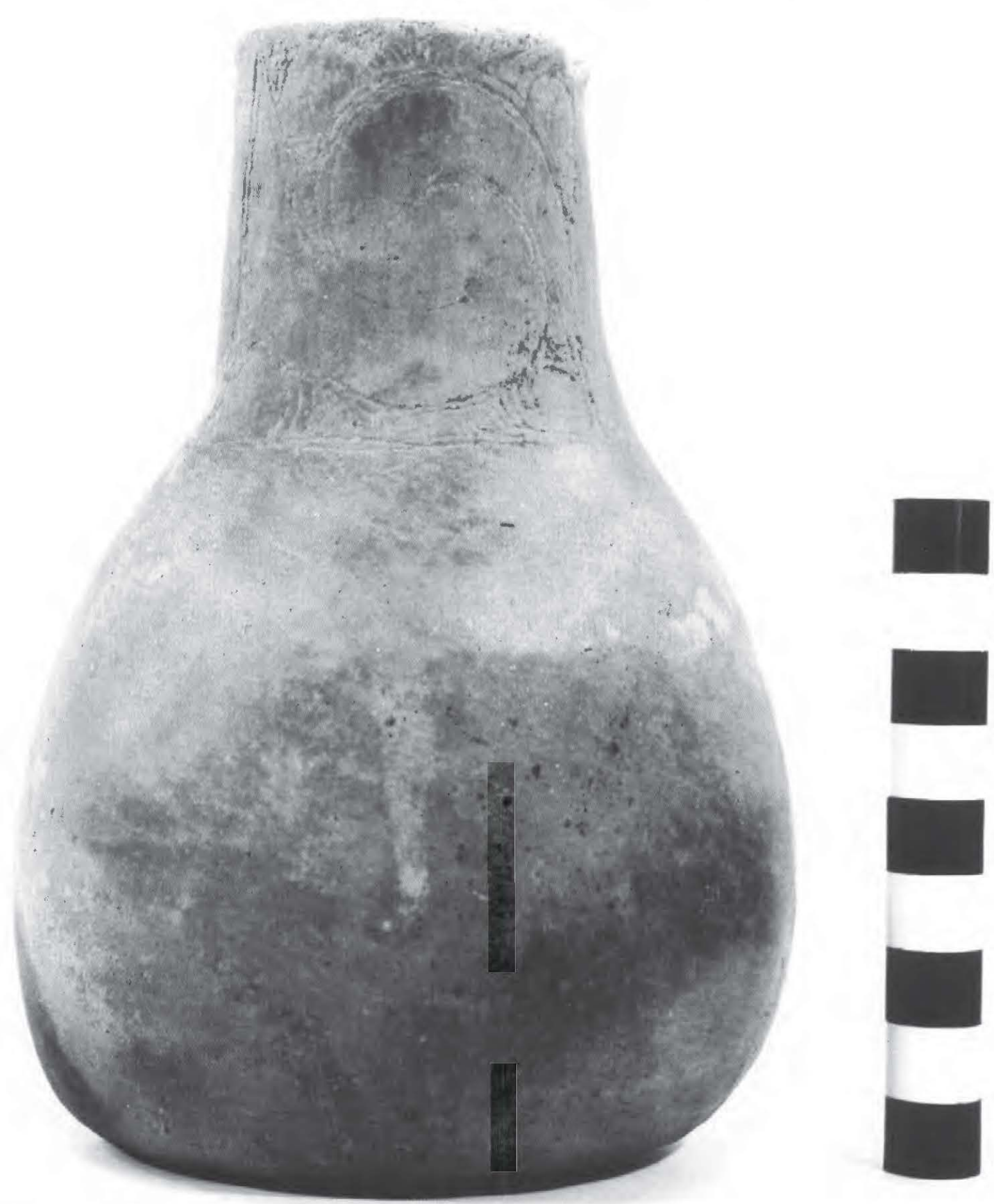

Figure 4. cf. Poynor Engraved, var. $L$ bottle, Burial 4, Mud Creek site.

INTERIOR SURFACE COLOR: dark grayish-brown; fire clouds on the rim and body EXTERIOR SURFACE COLOR: dark grayish-brown; fire clouds on the rim, body, and base WALL THICKNESS (RIM, BODY, AND BASE IN MM): rim, $4.9 \mathrm{~mm}$ 
INTERIOR SURFACE TREATMENT: burnished

EXTERIOR SURFACE TREATMENT: burnished

HEIGHT (IN CM): 10.8

ORIFICE DIAMETER (IN CM): 13.8

DIAMETER AT BOTTOM OF RIM OR NECK (IN CM): 13.7

BASE DIAMETER (IN CM) AND SHAPE OF BASE: 8.3 ; circular and flat

ESTIMATED VOLUME (IN LITERS): 0.89

DECORATION (INCLUDING MOTIF AND ELEMENTS WHEN APPARENT): The rim is divided into eight oval-shaped panels by a series of hatched engraved brackets or panel dividers. The top and bottom of the rim panel is defined by single horizontal engraved lines (Figure 5).

PIGMENT USE AND LOCATION ON VESSEL: none

TYPE AND VARIETY [IF KNOWN]: Poynor Engraved, var. Hood (Perttula 2011:Figure 6-64e).
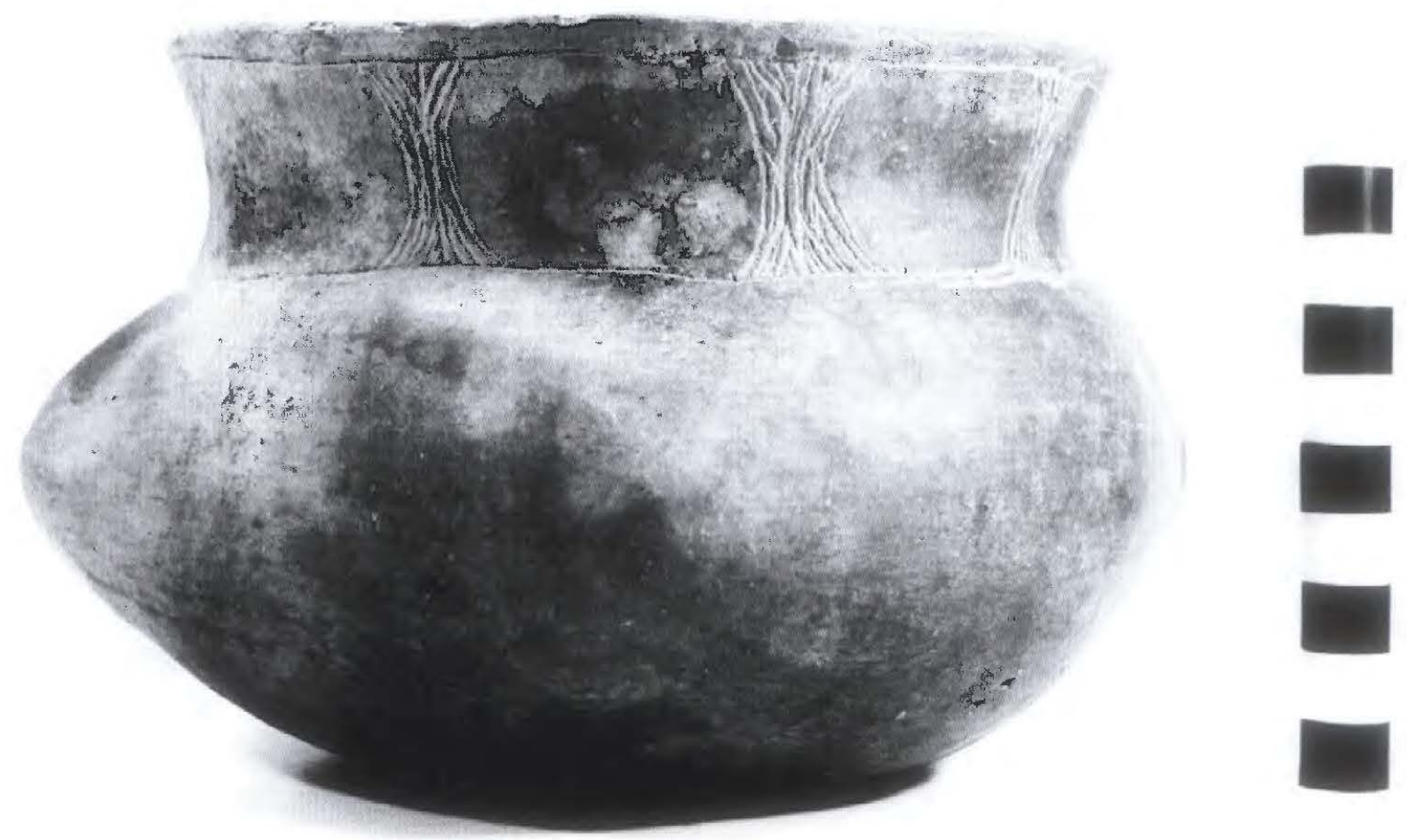

Figure 5. Poynor Engraved, var. Hood carinated bowl, Burial 4, Mud Creek site. 


\section{SUMMARY}

Four ancestral Caddo ceramic vessels from the Mud Creek site in Cherokee County, Texas have been documented in the Buddy Jones collection at the Gregg County Historical Museum from two burials in an unrecorded cemetery here. The vessels are grog-tempered fine wares from several different varieties of Poynor Engraved, a local fine ware madc by Frankston phase (ca. A.D. 1400-1650) Caddo peoples in the Neches-Angelina River basins. These different varieties, including cf. var. Blackburn, var. Hood, and regional variety Var. $L$ suggest that the Caddo cemetery was in use sometime between ca. A.D. 1400-1560 (Perttula 2011:Table 6-37).

\section{ACKNOWLEDGMENTS}

We appreciate the logistical support and assistance provided by Patti Haskins of the Gregg County Historical Museum. Lance Trask prepared Figure 1.

\section{REFERENCES CITED}

Perttula, T. K.

2011 The Ceramic Artifacts from the Lang Pasture Site (41AN38) and the Place of the Site within an Upper Neches River Basin Caddo Ceramic Tradition. In Archeological Investigations at the Lang Pasture Site (41AN38) in the Upper Neches River Basin of East Texas, assembled and edited by T. K. Perttula, D. B. Kelley, and R. A. Ricklis, pp. 145-320. Archeological Studies Program Report No. 129, Texas Department of Transportation, Environmental Affairs Division, Austin. 